\title{
Real-World Data Related to Non-Metastatic BreastCancer in Young Women: Experience of a Single Institution
}

\author{
Dados do Mundo Real sobre Câncer de Mama não Metastático em Mulheres Jovens: Experiência em uma Única Instituição \\ Datos del Mundo Real sobre Cáncer de Mama no Metastásico en Mujeres Jóvenes: Experiencia en una Sola Institución
}

\author{
Juliana Cunha e Silva Ominelli de Souza'; Andrew Sá Nunes'; Jesse Lopes da Silva'; Aline Coelho Gonçalves'; Susanne Crocamo \\ Ventilari da Costa ${ }^{1}$
}

Abstract

Introduction: Breast cancer is the leading cause of cancer-related deaths in women aged 20-59 years. Younger women usually have more aggressive tumors and more advanced disease with larger size and axillary lymph node involvement. There have been few studies assessing the characteristics of breast cancer in very young women. Objective: Evaluate the epidemiological and clinical profile of non-metastatic very young patients with breast cancer. Method: We performed a retrospective analysis to evaluate the epidemiological and clinical profile of non-metastatic breast cancer in patients $\leq 30$ years of age treated between 1993 and 2011 at the Brazilian National Cancer Institute José Alencar Gomes da Silva. We evaluated relapse-free survival (RFS) and overall survival (OS). Results: Of the 196 patients evaluated, $181(90 \%)$ had ductal carcinoma, 79 (40\%) had high-grade tumors, and $102(52 \%)$ had hormone receptor-positive tumors. 117 patients (60\%) had stage III disease at diagnosis. The median age was 29 years (range, 17-30 years). Of 185 patients who underwent surgery, $156(84.3 \%)$ underwent total mastectomy and 171 (92\%) underwent axillary lymph node dissection. 119 patients received neoadjuvant chemotherapy, and 14 patients (9.3\%) underwent neoadjuvant radiotherapy. After a median follow-up of 81.5 months, 109 patients (55\%) had relapsed and 81 (41\%) had died. The median RFS and OS were 49.5 months and 134 months, respectively. Lymph node involvement and neoadjuvant chemotherapy were associated with shorter RFS and OS. Conclusion: Breast cancer is uncommon in young patients, especially in those $\leq 30$ years of age. We found a predominance of locally advanced disease and worse prognostic pathological characteristics. Despite the aggressive treatment, our patients had worse outcomes than those reported by other authors.

Key words: Breast Neoplasms; Young Adult; Health Services Research.

\section{Resumo}

Introduçáo: $\mathrm{O}$ câncer de mama é a principal causa de morte relacionada ao câncer em pacientes de 20 a 59 anos. Mulheres jovens costumam ter tumores mais agressivos, maiores e com envolvimento nodal. Na literatura, existem poucos estudos avaliando as características do câncer de mama em mulheres muito jovens. Objetivo: Avaliar o perfil clínico de pacientes muito jovens com câncer de mama não metastático. Método: Análise retrospectiva para avaliar o perfil clínico e epidemiológico das pacientes com câncer de mama não metastático com 30 anos ou menos, tratadas entre 1993 e 2011, no Instituto Nacional de Câncer José Alencar Gomes da Silva. Resultados: Dos 196 pacientes analisados, 181 pacientes $(90 \%)$ possuíam carcinoma ductal infiltrante, $79(40 \%)$ possuíam tumores de alto grau e 102 (52\%), tumores com receptor hormonal positivo. 117 pacientes (60\%) foram classificados como tendo doença estágio III ao diagnóstico. A mediana idade foi de 29 anos (variando de 17-30 anos). Dos 185 pacientes que foram submetidos à cirurgia, $156(84,3 \%)$ à mastectomia e 171 (92\%) a esvaziamento axilar. Após o seguimento mediano de 81,5 meses, houve 109 recidivas $(55 \%)$ e 81 mortes (41\%). Sobrevida livre de progressão (SLP) e sobrevida global (SG) medianas foram de 49,5 meses e 134 meses, respectivamente. Envolvimento nodal e quimioterapia neoadjuvante foram associadas à SLP e à SG mais curtas. Conclusáo: $\mathrm{O}$ câncer de mama não é frequente em pacientes jovens, especialmente com menos de 30 anos. Foram encontradas mais doenças localmente avançadas e com piores características patológicas. Apesar do tratamento agressivo, as pacientes tiveram piores desfechos que os reportados por outros autores.

Palavras-chave: Neoplasias de Mama; Adulto Jovem; Pesquisa sobre Serviços de Saúde.
Resumen

Introducción: El Cáncer de mama es la causa principal de muertes relacionadas con el cáncer en mujeres de 20 a 59 años. Las mujeres jóvenes generalmente tienen tumores más agresivos y una enfermedad más avanzada con un tamańo mayor y con más implicación ganglionar axilar. Existen pocos estudios que evalúen las características del cáncer de mama en mujeres muy jóvenes. Objetivo: Evaluar el perfil clínico de pacientes muy jóvenes con cáncer de mama no metastásico. Método: Análisis retrospectivo para evaluar el perfil epidemiológico y clínico de pacientes con cáncer de mama no metastásico con 30 ańos de edad y menores tratados entre 1993 y 2011 en el Instituto Nacional del Cáncer José Alencar Gomes da Silva. Resultados: De los 196 pacientes evaluados, 181 pacientes (90\%) tenían carcinoma ductal, 79 (40\%) tumores de alto grado y $102(52 \%)$ eran positivos para los recursos humanos. La edad mediana fue de 29 ańos (rango: 17-30 ańos). De los 185 pacientes que se sometieron a cirugía, $156(84,3 \%)$ tuvieron mastectomía total y 171 (92\%) tuvieron disección de los ganglios axilares. 119 pacientes recibieron quimioterapia neoadyuvante. Después de una mediana de seguimiento de 81.5 meses, hubo 109 recaídas (55\%) y 81 muertes (41\%). La mediana de RFS y OS fue de 49.5 meses y 134 meses, respectivamente. La afectación positiva del ganglio y la quimioterapia neoadyuvante se asociaron con una RFS y una SG más cortas. Conclusión: El cáncer de mama no es frecuente en pacientes jóvenes, especialmente menores de 31 ańos. Encontramos más enfermedad localmente avanzada y peores características pronósticas patológicas. A pesar del tratamiento agresivo, nuestros pacientes tuvieron peores resultados que los reportados por otros autores. Palabras clave: Neoplasias de la Mama; Adulto Joven; Investigación en Servicios de Salud.

\footnotetext{
1 Oncologist. Department of Clinical Oncology of the Instituto Nacional de Câncer José Alencar Gomes da Silva (INCA), Rio de Janeiro (RJ), Brazil. Address for correspondence: Rua André Cavalcanti, 37,6ªndar do prédio anexo. Rio de Janeiro (RJ), Brazil. CEP 20231050. E-mail: juominelli@hotmail.com.
} 


\section{INTRODUCTION}

Breast cancer remains the leading cause of cancerrelated deaths in women aged 20 to 59 years in the United States. The American Cancer Society estimated that, in 2015, 231,840 women would be diagnosed with breast cancer and 40,290 would die from the disease ${ }^{1}$. According to the Brazilian Breast Cancer database and the Information Technology Department of the Brazilian National Ministry of Health Unified Health Care System, 31,195 cases of breast cancer were identified in Brazil between 2009 and 2012, 10.6\% of those cases having occurred in women under 40 years of age ${ }^{2}$.

In younger women, breast cancer is typically diagnosed after a palpable mass has been detected, given that such women rarely undergo screening mammograms ${ }^{3}$. The Brazilian recommendation for breast cancer screening is an annual clinical breast examination starting at age 40 and biennial mammograms between the ages of 50 and 69 years. For high-risk women, an annual clinical breast examination and mammogram is recommended beginning at age $35^{4}$.

Young women with breast cancer usually have more aggressive tumors i.e., tumors that are poorly differentiated, are hormone receptor-negative, and show overexpression of human epidermal growth factor receptor 2 (HER2) and more advanced disease, with larger tumors and axillary lymph node involvement ${ }^{5}$. Such women often need, and receive, more aggressive multimodal treatment.

Breast cancer, at any age, has great psychological, functional, and social impacts. Women with breast cancer face the treatment of a potentially fatal disease, the effects of aggressive treatment, and the destruction of their self-image. In the younger age groups, there is an associated impact on plans for motherhood and professional career goals.

There have been few studies assessing the characteristics of breast cancer in younger women in Brazil. We performed a retrospective analysis to evaluate the epidemiological and clinical profiles of young female patients with nonmetastatic breast cancer treated at the Brazilian Instituto Nacional do Câncer (INCA, National Cancer Institute), in the city of Rio de Janeiro, Brazil.

\section{METHOD}

This study was approved by the Ethics in Human Research Committee of the INCA in November 2014 (Reference no. 37517314.5.0000.5274) and was conducted in accordance with the Declaration of Helsinki and Good Clinical Practice guidelines. All participating patients gave written informed consent.
Through a search of the INCA database, we identified 249 young women with breast cancer treated at the INCA between 1993 and 2011. We considered "very young women" those $\leq 30$ years of age at diagnosis. We retrospectively reviewed the medical records and collected data about clinicopathological and treatment characteristics.

All of the patients underwent biopsy, and the tumor samples were reviewed at our institution. Pathological variables such as histological grade, estrogen-receptor (ER) status, and progesterone-receptor (PR) status had always been evaluated at the INCA, whereas we began evaluating HER2 status in 2007. Tumors with $>1 \%$ nuclearstained cells were considered positive for ER or PR. The histological grade was reported in accordance with the Bloom and Richardson histologic grading scheme: welldifferentiated (low grade, G1); moderately differentiated (intermediate grade, G2); and poorly differentiated (high grade, G3). The HER2 immunohistochemical staining (Herceptest; Dako A/S, Glostrup, Denmark) was scored from 0 to $3+$ : scores of 0 and $1+$ were considered negative; a score of $3+$ was considered positive; and a score of $2+$ was considered inconclusive, requiring additional testing with fluorescent in situ hybridization (FISH, PathVysion HER2 DNA probe kit; Vysis Inc., Downers Grove, IL, USA).

The tumor stage was based on the 7th Edition of the American Joint Committee on Cancer Staging Manual. We defined the pathological complete response (pCR) as ypT0/is ypN0: no invasive residual disease in breast tissue or lymph nodes. Weight and height information was collected during the first visit with the oncologist. Body mass index (BMI) categories were selected according to the World Health Organization definition: underweight, < $18.5 \mathrm{~kg} / \mathrm{m}^{2}$; normal weight, $18.5-25.0 \mathrm{~kg} / \mathrm{m}^{2}$; overweight, $25.0-30.0 \mathrm{~kg} / \mathrm{m}^{2}$; and obese $\geq 30.0 \mathrm{~kg} / \mathrm{m}^{2}$.

\section{StATISTICAL ANALYSIS}

Relapse-free survival (RFS) was defined as the time from the histological diagnosis to relapse, death, or the last follow-up evaluation. Overall survival (OS) was defined as the time from the histological diagnosis to death or the last follow-up evaluation. The RFS and OS were estimated using the Kaplan-Meier method and compared by log-rank test.

We used Cox proportional regression to estimate hazard ratios and the $95 \%$ confidence intervals. The variables with $\mathrm{p}<0.05$ in the univariate analysis were included in the multivariate analysis. We conducted multivariate analysis through manual selection, using a hierarchical model, beginning with demographic characteristics, then tumor characteristics and treatment. In each block, the non-significant variables were excluded. 
Baseline characteristics were compared with Fisher's exact test or the chi-square test, as appropriate. Values of $\mathrm{p}<0.05$ were considered significant. All analyses were performed with the Statistical Package for the Social Sciences, version 18.0 (SPSS Inc., Chicago, IL, USA).

\section{RESULTS}

Between January 1993 and July 2011, 249 patients aged 30 years or younger were diagnosed with breast cancer at the INCA. Of those patients, 53 were excluded (41 had metastasis at diagnosis and 21 were treated elsewhere).

The characteristics of the tumors and treatments are summarized in Table 1 . The median age was 29 years (range, 17-30 years). Of the 196 patients evaluated, 181 (92.3\%) had ductal carcinoma, 4 (2\%) had lobular carcinoma, and $10(5.1 \%)$ had other histological subtypes (metaplastic or sarcoma). High-grade tumors were identified in 79 patients (40\%). As for the immunohistochemical assay, 102 patients (52\%) had hormone-receptor positive tumors. The HER2 status was evaluated in only 79 patients (40\%). Among those 79 patients, the tumor was found to be HER2enriched in 19 (24\%). There were 27 patients (34\%) with triple-negative tumors. The tumor staging at diagnosis was stage III in 117 patients (60\%), stage II in 55 (28\%), and stage I in $23(12 \%)$.

As shown in Table 1, 185 patients (94.5\%) underwent surgery: total mastectomy in $156(84.3 \%)$ and breastconserving surgery in $29(15.0 \%)$. A total of 171 patients (92\%) underwent axillary lymph node dissection.

Of the 119 patients who received neoadjuvant chemotherapy, 21 (17.5\%) were diagnosed with stage II, $98(81.6 \%)$ were diagnosed with stage III, $103(85.8 \%)$ underwent radical mastectomy, and 106 (88.3\%) underwent axillary dissection. Only three patients (2.5\%) had a pCR: two were initially diagnosed with stage II and one was initially diagnosed with stage III. Eleven patients $(9.2 \%)$ received neoadjuvant therapy and did not undergo surgery, because the tumor remained inoperable or had metastasized (stage III at diagnosis). Fourteen patients (9.3\%) underwent neoadjuvant radiotherapy as a secondline neoadjuvant treatment.

The chemotherapy regimens most often applied consisted of anthracyclines, with or without a taxane. As can be seen in Table 2, 60 patients (31.5\%) received sequential anthracyclines plus a taxane (6-8 cycles); $119(62.6 \%)$ received an anthracycline-based regimen without a taxane (4-6 cycles), and 11 (5.7\%) received the cyclophosphamide, methotrexate, and 5-fluorouracil regimen. 150 patients $(76 \%)$ underwent radiotherapy, most often as adjuvant treatment. Ninety-five (94.1\%) of the 101 hormone receptor-positive patients received adjuvant tamoxifen, and one patient received neoadjuvant endocrine therapy. Six hormone receptor-positive patients did not receive any hormone therapy: one patient missed the follow-up appointment, and five had relapsed before starting the adjuvant treatment.

After a median follow-up of 81.5 months, 109 patients (55\%) had relapsed and 81 (41\%) had died. The median RFS was 49.5 months; the 5-year and 10-year relapse rates were $50 \%$ and $37 \%$, respectively (Figure 1). The univariate analysis identified the following factors as being significantly associated with relapse: being under 29 years of age $(\mathrm{p}=0.016 ; \mathrm{HR}=1.54 ; 95 \% \mathrm{CI}: 1.09-2.32)$, receiving neoadjuvant chemotherapy $(\mathrm{p}<0.001 ; \mathrm{HR}=$ 3.35; 95\% CI: 2.11-5.31), lymph node involvement ( $\mathrm{p}<$ $0.001 ; \mathrm{HR}=3.01 ; 95 \% \mathrm{CI}: 1.88-4.82)$, and having stage III disease at diagnosis ( $\mathrm{p}<0.001$; $\mathrm{HR}=2.77$; $95 \% \mathrm{CI}$ : $1.80-4.25)$. As can be seen in Table 3, the factors that
A

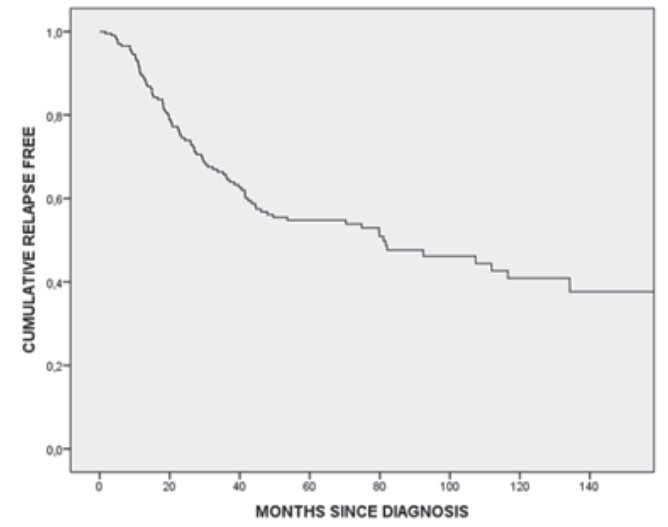

B

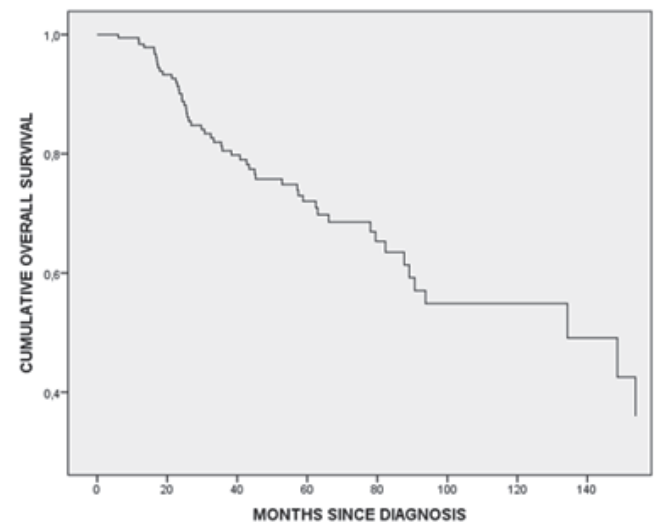

Figure 1. Kaplan-Meier curves for relapse-free survival (A) and overall survival (B) 
Table 1. Characteristics of young female patients with breast cancer, according to the staging at diagnosis

\begin{tabular}{|c|c|c|c|c|c|}
\hline Characteristic & $\begin{array}{c}\text { Total } \\
\left(n=196^{*}\right)\end{array}$ & $\begin{array}{l}\text { Stage I } \\
(n=23)\end{array}$ & $\begin{array}{l}\text { Stage II } \\
(n=55)\end{array}$ & $\begin{array}{l}\text { Stage III } \\
(n=117)\end{array}$ & p-valuet \\
\hline Age (years), median (range) & $29(17-30)$ & $29(19-30)$ & $29(17-30)$ & $28(20-30)$ & 0.34 \\
\hline Body mass index $\left(\mathrm{kg} / \mathrm{m}^{2}\right)$, median (range) & $24(16-41.9)$ & $24(19-42)$ & $22.8(16-42)$ & $24(17-36)$ & 0.09 \\
\hline \multicolumn{6}{|l|}{ Ethnicity, n (\%) } \\
\hline White & $94(48)$ & $13(56)$ & $28(51)$ & $53(45)$ & 0.72 \\
\hline Non-White & $59(30)$ & $5(21)$ & $18(32)$ & $36(30)$ & \\
\hline No data & $43(22)$ & $5(21)$ & $9(16)$ & $28(23)$ & \\
\hline \multicolumn{6}{|l|}{ Receptor status, n (\%) } \\
\hline Positive & $102(52)$ & $16(70)$ & $27(50)$ & $59(50)$ & 0.17 \\
\hline Negative & $86(44)$ & $6(26)$ & $26(47)$ & $54(46)$ & \\
\hline No data & $8(4)$ & $1(4)$ & $2(3)$ & $4(4)$ & \\
\hline \multicolumn{6}{|l|}{ HER2 status, n (\%) } \\
\hline Positive & $19(24)$ & $1(5)$ & $4(7)$ & $14(12)$ & 0.17 \\
\hline Negative & $58(73)$ & $8(35)$ & $19(35)$ & $31(26)$ & \\
\hline Triple-negative & $27(34)$ & - & $11(47)$ & $14(31)$ & \\
\hline No data & $117(60)$ & $14(60)$ & $32(58)$ & $72(62)$ & \\
\hline \multicolumn{6}{|l|}{ Histological grade, n (\%) } \\
\hline 1 or 2 & $76(38)$ & $11(48)$ & $20(36)$ & $45(39)$ & 0.36 \\
\hline 3 & $79(40)$ & $6(26)$ & $25(46)$ & $47(40)$ & \\
\hline No data & $41(21)$ & $6(26)$ & $10(18)$ & $25(21)$ & \\
\hline \multicolumn{6}{|l|}{ Lymph node involvement, n (\%) } \\
\hline Positive & $110(56)$ & $3(13)$ & $28(51)$ & 79 (67) & $<0.01$ \\
\hline Negative & $72(37)$ & $20(86)$ & $27(49)$ & $25(21)$ & \\
\hline No data & $14(7)$ & & 0 & $13(11)$ & \\
\hline \multicolumn{6}{|l|}{ Chemotherapy, n (\%) } \\
\hline Neoadjuvant & $120(61)$ & 0 & $21(38)$ & $98(84)$ & $<0.01$ \\
\hline Adjuvant & $70(35)$ & $20(87)$ & $33(60)$ & $17(14)$ & \\
\hline Not done & $6(3)$ & $3(13)$ & $1(2)$ & $2(2)$ & \\
\hline \multicolumn{6}{|l|}{ Hormonal therapy, n (\%) } \\
\hline Neoadjuvant & $2(1)$ & 0 & 0 & $2(2)$ & 0.17 \\
\hline Adjuvant & $102(52)$ & $16(70)$ & $28(51)$ & $58(49)$ & \\
\hline Not done & $92(46)$ & $7(30)$ & $27(49)$ & $57(49)$ & \\
\hline Radiotherapy, n (\%) & & & & & $<0.01$ \\
\hline Neoadjuvant & $14(7)$ & 0 & 0 & $14(12)$ & \\
\hline Adjuvant & $136(69)$ & $15(65)$ & $42(76)$ & $79(67)$ & \\
\hline Not done & $46(23)$ & $8(34)$ & $13(23)$ & $24(20)$ & \\
\hline \multicolumn{6}{|l|}{ Type of surgery, n (\%) } \\
\hline Breast-conserving & $29(14)$ & $13(56)$ & $10(18)$ & $6(5)$ & $<0.01$ \\
\hline Total mastectomy & $156(79)$ & $10(44)$ & $45(82)$ & $101(86)$ & \\
\hline None & $11(5)$ & 0 & 0 & $10(9)$ & \\
\hline \multicolumn{6}{|l|}{ Nodal treatment, n (\%) } \\
\hline Axillary dissection & $171(87)$ & $17(74)$ & $48(87)$ & $106(90)$ & $<0.01$ \\
\hline Sentinel node biopsy & $14(7)$ & $6(26)$ & $7(13)$ & $1(1)$ & \\
\hline No data & $11(5)$ & 0 & 0 & $10(9)$ & \\
\hline
\end{tabular}

* The sum of patients per stage was 195 because the information on the stage at diagnosis was missing for one patient.

†chi-square test. 
Table 2. Chemotherapy regimens

\begin{tabular}{l|c|c}
\hline \multirow{2}{*}{ Composition } & \multicolumn{2}{|c}{ Category } \\
\cline { 2 - 3 } & Neoadjuvant & Adjuvant \\
\hline Anthracycline, n (\%) & $69(57 \%)$ & $50(71 \%)$ \\
\hline $\begin{array}{l}\text { Anthracycline + } \\
\text { taxane, n (\%) }\end{array}$ & $46(38 \%)$ & $14(20 \%)$ \\
\hline Other, n (\%) & $5(4 \%)$ & $6(8 \%)$ \\
\hline $\mathrm{p}=0.014$.
\end{tabular}

retained their significance as independent predictors of relapse in the multivariate analysis were lymph node involvement $(\mathrm{p}<0.001 ; \mathrm{HR}=2.45 ; 95 \%$ CI: 1.52-3.94) and receiving neoadjuvant chemotherapy $(\mathrm{p}<0.001$; HR $=2.88 ; 95 \%$ CI: $1.79-4.69)$.

The median OS was 134 months. The 5-year survival rate was $63.4 \%$, and the 10 -year survival rate was $52.6 \%$ (Figure 1). In the univariate analysis, the factors found to be significantly associated with overall survival were as follows: being under 29 years of age $(\mathrm{p}=0.016$; $\mathrm{HR}=1.70 ; 95 \% \mathrm{CI}: 1.09-2.65)$, having a hormone receptor-negative tumor $(\mathrm{p}<0.001 ; \mathrm{HR}=2.21 ; 95 \%$ CI: 1.40-3.47), receiving neoadjuvant chemotherapy (p $<0.001 ; \mathrm{HR}=3.84 ; 95 \% \mathrm{CI}: 2.20-6.70)$, lymph node involvement $(\mathrm{p}<0.001 ; \mathrm{HR}=2.72 ; 95 \% \mathrm{CI}: 1.57-4.71)$, and having stage III disease at diagnosis $(\mathrm{p}<0.001 ; \mathrm{HR}$ $=3.71 ; 95 \%$ CI: 2.17-6.36). As can be seen in Figure 2, the factors that retained their significance as independent predictors of relapse in the multivariate analysis were having a hormone receptor-negative tumor $(\mathrm{p}<0.001$; $\mathrm{HR}=2.1 ; 95 \% \mathrm{CI}: 1.28-3.44)$, lymph node involvement $(\mathrm{p}<0.001 ; \mathrm{HR}=2.71 ; 95 \% \mathrm{CI}: 1.51-4.87)$, and receiving neoadjuvant chemotherapy $(\mathrm{p}<0.001 ; \mathrm{HR}=2.95 ; 95 \%$ CI: 1.63-5.32).

Because of the small sample size, we were unable to evaluate the use of trastuzumab or the use of radiotherapy as prognostic factors.

\section{DISCUSSION}

Breast cancer is uncommon in young patients, especially in those 30 years of age or younger. However, it is the leading cause of cancer death in women over the age of $20^{1}$. Although previous studies have evaluated breast cancer in women under 40 years of age, there has been little research involving women in younger age brackets, such as those evaluated in the present study (women $\leq 30$ years of age).

Of the 196 female breast cancer patients $\leq 30$ years of age evaluated in the present study had a hormone receptorpositive tumor. Of the patients who had their HER2 status evaluated, a quarter were diagnosed with HER2 overexpression and 34\% were diagnosed with triple-negative tumors. In previous analyses, immunohistochemical findings vary widely: hormone receptor-positive (48-77\%), HER2-positive status (19-33\%), triple-negative (15-24\%), and high histological grade (34-50\%) $)^{5,6}$. When compared with older women, the patients in our sample had tumors that were higher grade, more HER2-enriched, and more likely to be triple-negative. Therefore, our patients appear to have had tumors with even more aggressive features: more triple-negative tumors and fewer hormone receptorpositive tumors.

Patients with tumors of the HER2-positive and triplenegative subtypes have shorter survival regardless of the age at diagnosis ${ }^{6}$. We also found that hormone receptor positivity was associated with longer overall survival. Although the Early Breast Cancer Trialists' Collaborative Group (EBCTCG) showed, in a meta-analysis, a 29\% reduction in cancer-related mortality in women under 45 years of age who had been treated with tamoxifen for 5 years ${ }^{7}$, being younger seems to be associated with worse outcomes in patients with hormone receptorpositive tumors, even with adjuvant endocrine therapy ${ }^{6,8}$. That distinct age-related benefit could be explained by lower adherence to endocrine therapy, less occurrence of chemotherapy-related amenorrhea ${ }^{9}$, tamoxifen resistance, the need for incremental ovarian suppression, or a combination of any of those factors ${ }^{10}$. In 2011, Hershman et al. ${ }^{11}$ showed that early discontinuation of and nonadherence to hormonal therapy (below $80 \%$ of dose) were both common and were both associated with increased mortality ${ }^{11}$. Furthermore, the Suppression of Ovarian Function Trial reported the benefits of adding ovarian

Table 3. Multivariate analysis for relapse-free survival and overall survival

\begin{tabular}{l|c|c|c|c|c}
\multirow{2}{*}{\multicolumn{1}{c|}{ Parameter }} & \multirow{2}{*}{ Comparison } & \multicolumn{2}{c|}{ Relapse-free survival } & \multicolumn{2}{c}{ Overall Survival } \\
\cline { 2 - 6 } & & HR (95\% CI) & P-value & HR (95\% CI) & P-value \\
\hline Age & $\leq 28$ vs. $>28$ years & $1.43(0.96-2.13)$ & 0.077 & $1.39(0.86-2.25)$ & 0.175 \\
\hline Hormone receptor status & Negative vs. positive & $1.450(0.98-2.13)$ & 0.061 & $2.1(1.28-3.44)$ & 0.001 \\
\hline Node involvement & Positive vs. negative & $2.45(1.52-3.94)$ & 0.001 & $2.7(1.51-4.80)$ & 0.001 \\
\hline Stage at diagnosis & III vs. I + II & $1.21(0.74-1.99)$ & 0.433 & $1.96(0.98-3.91)$ & 0.055 \\
\hline Chemotherapy & Neoadjuvant vs. adjuvant & $2.884(1.79-4.69)$ & 0.001 & $2.95(1.63-5.32)$ & 0.001 \\
\hline
\end{tabular}



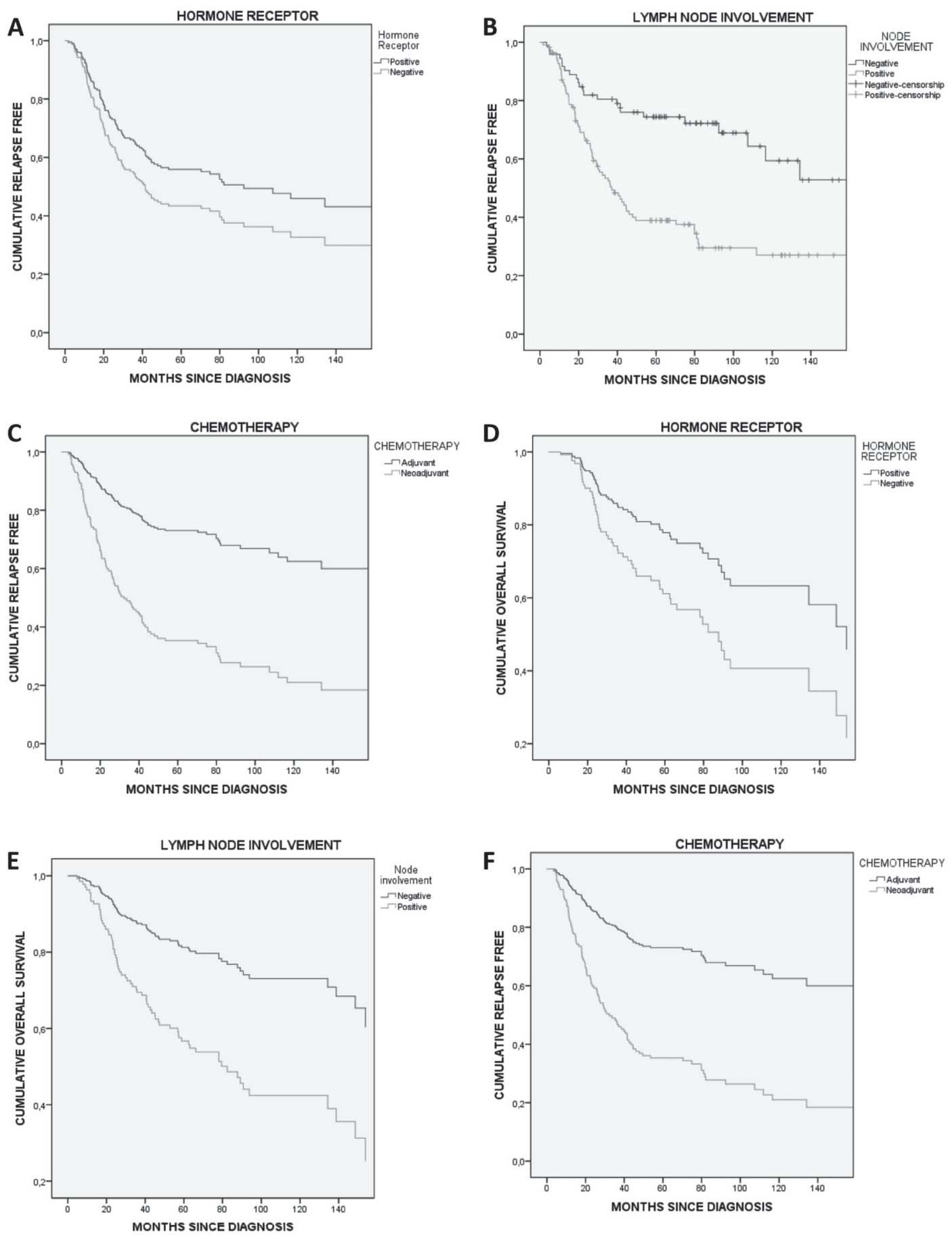

Figure 2. Kaplan-Meier relapse-free survival curves according to: (A) Hormone receptor; (B) Axillary lymph node involvement; (C) Chemotherapy timing; Kaplan-Meier overall survival curves according to: (D) Hormone receptor; (E) Axillary lymph node involvement; (F) Chemotherapy timing

suppression with aromatase inhibitor in premenopausal patients at high risk when compared with tamoxifen, with or without ovarian suppression ${ }^{10}$.

In Brazil, patients have more advanced tumors, at diagnosis, than do those in other countries, possibly due to the delays in diagnosis and disparities in the quality of health care service ${ }^{12,13}$. In the present study, $60 \%$ of the patients had stage III disease at the time of diagnosis and $60 \%$ had lymph node involvement, whereas studies conducted in other countries have reported that $20 \%$ of patients have stage III tumors ${ }^{8}, 20 \%$ have T3/T4 lesions ${ }^{14}$, and $35-50 \%$ have lymph node involvement ${ }^{5}$. In our study, lymph node involvement was an independent predictor of relapse and death, as reported in previous studies ${ }^{5,14}$. 
The chemotherapy regimens most commonly applied in our sample were those consisting of anthracyclines plus a taxane or consisting of higher-cumulative-dose anthracyclines. There was no significant difference between the chemotherapy regimens in terms of relapse or survival. That is in line with the EBCTCG meta-analysis findings, suggesting that extra cycles of a taxane could be counterbalanced by extra cycles of other cytotoxic drugs ${ }^{15}$.

In the present study, $60 \%$ of the patients received neoadjuvant chemotherapy, usually to ensure tumor resectability. Currently, neoadjuvant treatment is widely used to allow more conservative surgery ${ }^{16}$, which leads to lower morbidity and provides better cosmetic results ${ }^{17}$. However, it was initially applied in patients with locally advanced tumors in an attempt to make those tumors resectable. Randomized studies have shown that the timing of chemotherapy has no impact on survival ${ }^{18}$ but allows the evaluation of tumor response, surgical procedures that are more conservative ${ }^{16}$, and the early treatment of micrometastases.

The achievement of a pCR is an important prognostic factor $^{16}$, especially in triple-negative and HER2-positive tumors. In 2005, the Herceptin Adjuvant (HERA) trial showed that trastuzumab increased disease-free survival in patients with HER2-positive breast cancer ${ }^{19}$. In 2006, the U.S. Food and Drug Administration approved trastuzumab for the adjuvant treatment of breast cancer in patients with HER2-positive tumors. However, at the INCA, it was not possible to evaluate HER2 until 2007, and it was therefore evaluated in only $40 \%$ of the patients in our sample. Despite the HERA results in 2005, trastuzumab was not available at after the INCA until 2008. Because only 12 of the patients in our sample received the drug, we were unable to evaluate its use as a prognostic factor.

Neoadjuvant chemotherapy is the gold standard treatment for locally advanced breast cancer, producing an objective clinical response in $80-90 \%$ of patients ${ }^{20}$ and a pCR in $20-40 \%{ }^{16}$. We found pCR rates of $2.5 \%$ and the tumors remained unresectable after neoadjuvant chemotherapy in 21 patients (17.6\%). Fourteen patients $(11.7 \%)$ received neoadjuvant radiotherapy, with or without chemotherapy, and 10 (71.4\%) of those patients underwent surgery thereafter. This approach has been tested in patients with chemotherapy-refractory tumors, in whom it was found to be well-tolerated and to produce a good clinical response ${ }^{21}$. In 2007, Gaui et al. ${ }^{21}$ reported that 23 of 28 patients became candidates for surgery after having been submitted to this approach. However, Coelho et al..$^{22}$ reported frequent surgical complications, although no deaths were related to the procedure.

A pCR has been found to be more common among patients who carry the BRCA1 gene mutation than among those who do not or who carry the BRCA2 mutation ${ }^{23}$. However, it is not recommended to select the chemotherapy regimen on the basis of the genetic findings. Genetic counseling should be considered for all patients under 40 years of age, especially for those with a family history of breast cancer or with a triple-negative tumor ${ }^{24}$. During the present study, neither genetic counseling nor genetic testing were available.

Conservative breast surgery in patients $\leq 30$ years of age is a controversial issue in the literature, and there are conflicting findings regarding the increased risk of local relapse. Randomized trials conducted in the 1980s and 1990s showed equivalence between treatments. However, those trials evaluated outdated chemotherapy and radiotherapy treatments, with few younger patients in their samples. The most recent trials have shown that, despite the fact that it increases the risk of local relapse, conservative surgery has no significant impact on survival $^{25}$. Being young is no longer a contraindication to breast-conserving therapy. In our sample, nearly $90 \%$ of the patients underwent mastectomy, with or without axillary lymph node dissection, because of locally advanced disease.

Our study has some limitations. The retrospective design raises the possibility of missing clinical data in the patient records. Other possible limitations include the fact that the HER2 status was evaluated in very few of the cases, the lack of comparison with other age groups or a control population, and the relatively short follow-up period, especially for hormone receptor-positive patients. However, it is one of the largest studies conducted to date including such young patients and reflects the reality in developing countries.

\section{CONCLUSION}

Our analysis showed that, in a very young population of women with breast cancer, locally advanced disease was more common and the pathological characteristics indicated a worse prognosis. Despite aggressive treatment, our patients had poor outcomes.

\section{AUTHOR CONTRIBUTIONS}

Juliana Cunha e Silva Ominelli de Souza and Jesse Lopes da Silva conceived and designed the work; collected, analyzed, and interpreted the data; revised the manuscript; and approved the final version for submission. Andrew Sá Nunes collected, analyzed, and interpreted the data; revised the manuscript; and approved the final version for submission. Aline Coelho Gonçalves and Susanne Crocamo Ventilari da Costa conceived and designed the 
work; interpreted the data; revised the manuscript; and approved the final version for submission.

\section{DECLARATION OF CONFLICTS OF INTEREST}

Nothing to Declare.

\section{REFERENCES}

1. Siegel RL, Miller KD, Jemal A. Cancer Statistics, 2016. CA Cancer J Clin. 2016;66(1):7-30.

2. Gravena AAF, Agnolo CMD, Lopes TCR, Demitto MO,William Augusto de Mello WA, Borghesan DHP, et al. Breast Cancer in Young Brazilian Women: Challenge for the Oncology Care. [Internet]. Epidemiology Research International; 2014. [acesso em 2018 maio 5]. Disponível em: https://www.hindawi.com/journals/ eri/2014/261625/cta/

3. Instituto Nacional de Câncer José Alencar Gomes da Silva. Estimate 2016: Cancer Incidence in Brazil. INCA; 2015.

4. Gajdos C, Tartter PI, Bleiweiss IJ, Bodian C, Brower ST. Stage 0 to stage III breast cancer in young women. J Am Coll Surg. 2000;190(5)523-9.

5. Zhao Y, Xiaoqiu D, Li R, Song J, Zhang D. Correlation Between Clinical-Pathologic Factors and Long-Term Follow-Up in Young Breast Cancer Patients. Transl Oncol. 2015;8(4):265-72.

6. Park YH, Lee SJ, Jung HA, Kim SM, Kim MJ, Kil $\mathrm{WH}$, et al. Prevalence and clinical outcomes of young breast cancer (YBC) patients according to intrinsic breast cancer subtypes: Single institutional experience in Korea. Breast. 2015;24(3):213-7.

7. Early Breast Cancer Trialists' Collaborative Group. Relevance of breast cancer hormone receptors and other factors to the efficacy of adjuvant tamoxifen: patient-level meta-analysis of randomised trials. Lancet. 2011;378(9793):771-84.

8. Partridge AH, Hughes ME, Warner ET, Ottesen RA, Wong YN, Edge SB, et al. Subtype-Dependent Relationship Between Young Age at Diagnosis and Breast Cancer Survival. J Clin Oncol. 2016;34(27):3308-14.

9. Walshe JM, Denduluri N, Swain S.M. Amenorrhea in premenopausal women after adjuvant chemotherapy for breast cancer. J Clin Oncol. 2006;24(36):5769-79.

10. Francis PA, Regan MM, Fleming GF. Adjuvant Ovarian Suppression in Premenopausal Breast Cancer. N Engl J Med. 2015;372(5)436-46.

11. Hershman DL, Shao T, Kushi LH, Buono D, Tsai WY, Fehrenbacher L, et al. Early discontinuation and nonadherence to adjuvant hormonal therapy are associated with increased mortality in women with breast cancer. Breast Cancer Res Treat. 2011;126(2)529-37.
12. Pinheiro AB, Lauter DS, Medeiros GC, Cardozo IR, Menezes LM, Souza RMB, et al. Câncer de mama em mulheres jovens: análise de 12.689 casos. Rev Bras Cancerol. 2013;59(3):351-9.

13. Lee BL, Liedke PE, Barrios CH, Simon SD, Finkelstein DM, Goss PE. Breast cancer in Brazil: present status and future goals. Lancet Oncol. 2012;13(3):e95-e102.

14. Han W, Kang SY. Relationship between age at diagnosis and outcome of premenopausal breast cancer: age less than 35 years is a reasonable cut-off for defining young age-onset breast cancer. Breast Cancer Res Treat. 2010; 119(1):193-200.

15. Early Breast Cancer Trialists' Collaborative Group (EBCTCG). Comparisons between different polychemotherapy regimens for early breast cancer: meta-analyses of long-term outcome among 100,000 women in 123 randomised trials. Lancet. 2012;379(9814):432-44.

16. Killelea BK, Yang VQ, Mougalian S, Horowitz NR, Pusztai L, Chagpar AB, et al. Neoadjuvant chemotherapy for breast cancer increases the rate of breast conservation: results from the National Cancer Database. J Am Coll Surg. 2015;220(6):1063-9.

17. Curran D, van Dongen JP, Aaronson NK, Kiebert G, Fentiman IS, Mignolet F, et al. Quality of life of early-stage breast cancer patients treated with radical mastectomy or breast-conserving procedures: results of EORTC Trial 10801. Eur J Cancer. 1998;34(3)307-14.

18. van der Hage JA, van de Velde CJ, Julien JP, TubianaHulin M, Vandervelden C, Duchateau L. Preoperative chemotherapy in primary operable breast cancer: results from the European Organization for Research and Treatment of Cancer trial 10902. J Clin Oncol. 2001;19(22):4224-37.

19. Piccart-Gebhart MJ , M Procter M, B Leyland-Jones, Goldhirsch A , M Untch, Smith I, et al. Trastuzumab after Adjuvant Chemotherapy in HER2-Positive Breast Cancer. N Engl J Med. 2005;353(16):1659-72.

20. Rastogi P, Anderson SJ, Bear HD, Geyer CE, Kahlenberg MS, Robidoux A, et al. Preoperative Chemotherapy: Updates of National Surgical Adjuvant Breast and Bowel Project Protocols B-18 and B-27. J Clin Oncol. 2008;26(5):778-85.

21. Gaui MF, Amorim G, Arcuri RA, Pereira G, Moreira D, Djahjah C, Biasoli I, et al. A phase II study of secondline neoadjuvant chemotherapy with capecitabine and radiation therapy for anthracycline-resistant locally advanced breast cancer. Am J Clin Oncol. 2007;30(1):78-81.

22. Coelho RC, Da Silva FML, Do Carmo IML, Bonaccorsi BV, Hahn SM, Faroni LD, et al. Is there a role for salvage radiotherapy in locally advanced breast cancer refractory to neoadjuvant chemotherapy? Breast. 2016;31:192-6. 
23. Arun B, Bayraktar S, Liu DD, Gutierrez Barrera AM, Atchley D, Pusztai L, et al. Response to Neoadjuvant Systemic Therapy for Breast Cancer in BRCA Mutation Carriers and Noncarriers: A Single-Institution Experience. J Clin Oncol. 2011;29(28):3739-46.

24. Paluch-Shimon S, Pagani O, Partridge AH, Bar-Meir E, Fallowfield L, Fenlon D, et al. Second international consensus guidelines for breast cancer in young women (BCY2). Breast. 2016;26:87-99.

25. Mahmood U, Morris C, Neuner G, Koshy M, Kesmodel S, Buras R, et al. Similar survival with breast conservation therapy or mastectomy in the management of young women with early-stage breast cancer. Int J Radiat Oncol Biol Phys. 2012;83(5):1387-93.

Recebido em 6/3/2018

Aprovado em 3/5/2018 